\title{
Ethnopharmacological survey of herbal remedies used for treatment of various types of cancer and their methods of preparations in the West Bank-Palestine
}

\author{
Nidal Amin Jaradat*, Rowa Al-Ramahi, Abdel Naser Zaid, Ola Ibrahim Ayesh and Ahmad Mustafa Eid
}

\begin{abstract}
Background: Plants have been the primary source of medicines since life on earth; more than $50 \%$ of existing cancer treatments are derived from plants.

Methods: An ethnopharmacological survey of herbal remedies used in cancer treatment was carried out in the West Bank/ Palestine. A questionnaire was distributed to one hundred and fifty herbalists, traditional healers and rural dwellers. Collected information included the names of plants, the used parts, types of cancers for which these plants were used and also their methods of preparation. To identify the most important species used, Factor of informant's consensus $\left(F_{i c}\right)$, Fidelity level $(F I)$ and the Use-value (UV) were calculated.

Results: Collected data has shown that 72 plants are utilized for treatment of cancer, belonging to 44 families; from them Compositae and Lamiaceae were the most common. Leaves and fruits were the most commonly used parts, while decoctions, infusions and syrups were the main methods of preparation. Lung cancer was the most common type of cancer treated with these plants and Ephedra alata was the most commonly used plant for treatment of cancer in Palestine. The $F_{i c}$ was high for all the plants; FI was $100 \%$ for many plants, the highest UV (0.72) was for Ephedra alata.

Conclusions: This study showed that many herbal remedies are still used by herbalists in Palestine for treatment of cancer; some of them have been approved scientifically while others are not. A combined effort between informants and scientific institutions working in this field can help in the discovery of new anticancer agents. Moreover, scientists must explore the most suitable method of extraction, formulation and dose determination in order to achieve the best benefits from these herbals.
\end{abstract}

Keywords: Ethnopharmacology, Anticancer, Herbal remedies, Traditional use, Ephedra alata

\section{Background}

The Holy Land/ Palestine has miscellaneous ethnic groups (Muslims, Christians, Druze, Jews from East and West and Samaritans), so its characteristic cultures are numerous and varied, including folkloric herbal medicine. However, these traditions in herbal remedies have waned over hundreds of years. Palestine is a unique land, in its ecological diversity due to its geographical location between Africa, Asia and Europe. Different zoogeographic,

\footnotetext{
* Correspondence: nidaljaradat@najah.edu

Department of Pharmacy, Faculty of Medicine and Health Sciences, An-Najah National University, P.O. Box 7, Nablus, Palestine
}

climatic, and phytogeographic zones covered Palestine, creating great biological multi-diversity $[1,2]$. In addition to that it was as an important international trade crossroad from ancient times, between North Africa, East Asia and West Europe; this added to its culture in herbal medicines [3-5].

Plants provide a continual source of medicines for animals and humans; they have been used since ancient times in crude forms as decoctions, syrups, liniments, powders, infusions and ointments [6,7]. Evidence of medicinal plant use around 60000 years ago was found in a cave discovered in 1960 in the Middle East $[8,9]$. In 
recent time, people in both developed and developing countries utilize herbal medicines for improving their health [10-12]. According to the World Health Organization (WHO) evaluations, about $80 \%$ of populations in developing countries have utilized ethnomedicines for their health care requirements and more than $60 \%$ of cancer patients have used natural plant products with vitamins in fighting this disease [13-15]. While $50 \%$ of modern pharmaceutical medications in clinical practice are derived from plants, many of them have strong anticancer effects $[16,17]$.

According to the WHO and the American Cancer Society about eight million died from cancer and about fourteen million new cancer cases occurred in 2012. The highest percentages of patients were with lung, breast and colorectal cancers respectively. WHO also estimates a substantive increase up to nineteen million new cases of cancer per year by 2025, due to the growth of global population. More than half of all cancers and cancer deaths occurred in less developed countries, and these proportions may be further increased [18-20].

Nowadays, chemotherapeutic anticancer agents are the most common method of treatment, but they may cause serious side effects and toxicity [21-23].

Due to the high death rate among patients with cancer and the hazardous side effects and adverse reactions of the radiotherapy and chemotherapy, cancer patients often start seeking alternative methods of treatments, like herbal medicine with or instead of conventional medicine [24-26].

\section{Methods}

An ethnopharmacological survey on herbal remedies used for treatment of various types of cancer was conducted from March 2015 to June 2015. Areas visited included all regions of the West Bank/Palestine; Nablus, Jenin, Tubas, Toulkarm, Salfeit, Qalqilya, Ramallah, Jericho, Jerusalem, Bethlehem and Hebron (Fig. 1).

The study aims, protocols and the informed consent forms were approved by the Institutional Review Board (IRB) at An-Najah National University (IRB archived number $25 / \mathrm{Jan} / 2015$ ). The study was conducted in accordance with the requirements of the declarations of Helsinki.

The study was carried out by interviews with herbalists, traditional healers and rural dwellers that used herbal remedies in the treatment of different types of cancer. The number of registered herbalists in the West Bank is 222. According to the Raosoft calculator the minimum sample should be 141 participants, so we included 150 [27]. These informants represented most of the practitioners in this field in the West Bank (Sociodemographic characteristics are presented in Table 1).

A convenience sample of herbalists and practitioners from various regions were met by researchers and asked to answer a face to face questionnaire. They were interviewed in Arabic after getting their verbal consent only once.

Statistical analyses were performed by using Statistical Package for Social Sciences (SPSSversion17.0). Mean \pm

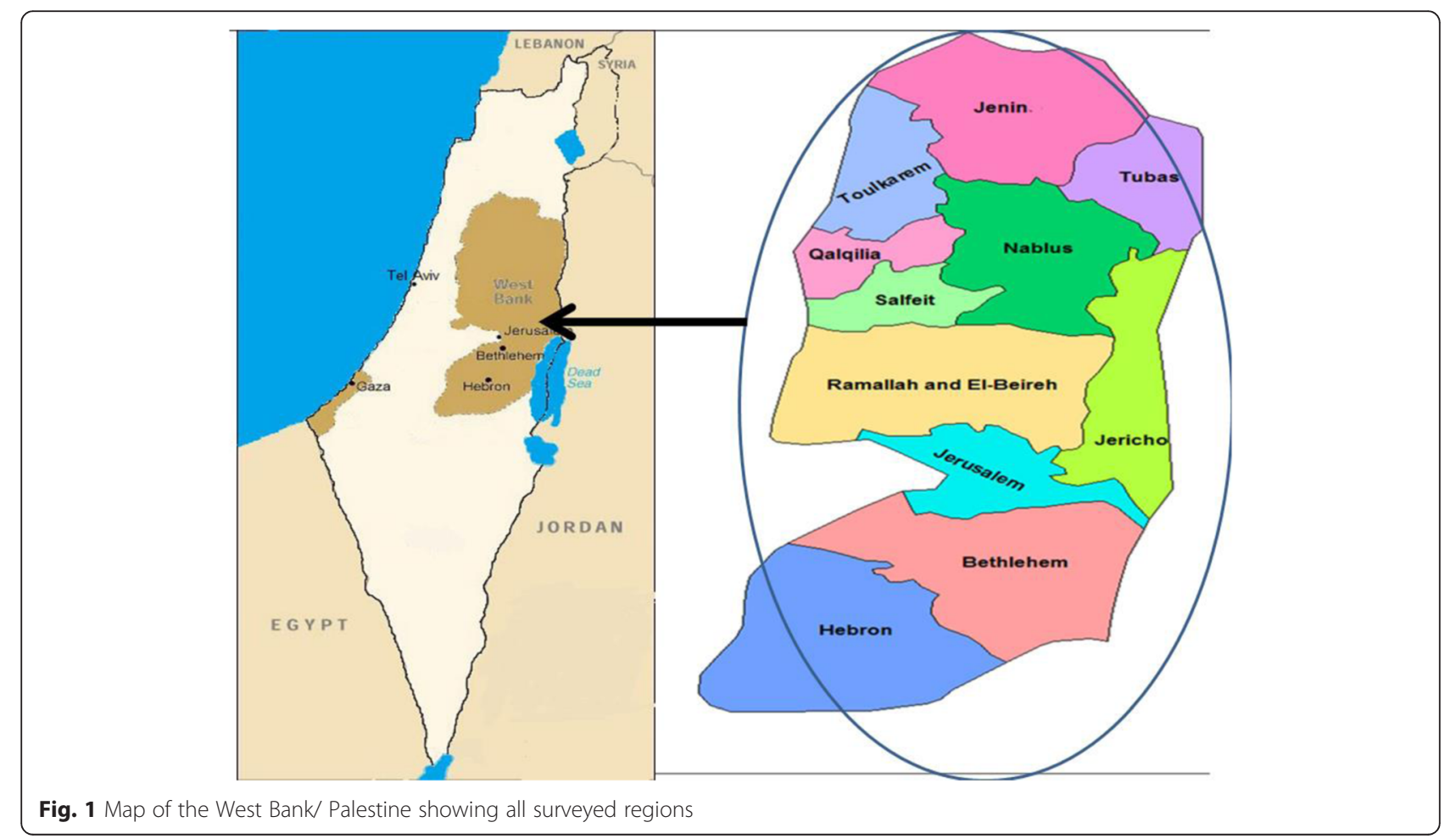


Table 1 Sociodemographic characteristics of the respondents

\begin{tabular}{ll}
\hline Variable & $N(\%)$ \\
\hline Gender & \\
Male & $128(85.3)$ \\
Female & $22(14.7)$ \\
Education level & \\
Uneducated & $26(17.3)$ \\
Elementary & $14(9.3)$ \\
Secondary school & $28(18.7)$ \\
High secondary school & $53(35.3)$ \\
Undergraduate & $27(18)$ \\
Graduate (higher education) & $2(1.3)$ \\
Residency & \\
Bethlehem & $13(8.7)$ \\
Hebron & $13(8.7)$ \\
Jenin & $21(14.0)$ \\
Jericho & $9(6.0)$ \\
Jerusalem & $10(6.7)$ \\
Nablus & $20(13.3)$ \\
Qalqilya & $7(4.7)$ \\
Ramallah & $14(9.3)$ \\
Salfeit & $18(12.0)$ \\
Tubas & $7(4.7)$ \\
Toulkarm & $18(12.0)$ \\
Age (mean \pm SD) years & $54.7(14.3)$ \\
Experience (mean \pm SD) years & $34.8(14.3)$ \\
& \\
& \\
& \\
&
\end{tabular}

standard deviation were computed for continuous data. Frequencies and percentages were calculated for categorical variables. Means were compared using Student's $t$ test. Categorical variables were compared using Chisquared and Fisher's exact tests, as applicable. A $p$-value of less than 0.05 was considered to be statistically significant for all analyses.

Questionnaires were administered through personal contact discussions. This method is an effective and easy option of data collection. This survey aimed to obtain information on the names of plants commonly used in the treatment of cancer, the type of cancer treated by herbs, the methods of preparing and the parts used for administration. Interviews were conducted in the Arabic language of the informants. Names of plants were translated later to English and Latin. In most cases, the interviews often started in the form of informal discussions to gain the confidence of the interviewees.

All of the 72 plant materials were collected from the interviewees (herbalists, traditional healers and rural dwellers) and kept in special glass frames and later identified by the pharmacognosist Dr. Nidal Jaradat. The identity of each plant species mentioned by the interviewees was confirmed and verified by using photographs and live specimens. A medicinal use was accepted as valid only if it was mentioned by at least three independent herbal practitioners. Samples of these collected herbs were given a herbarium specimen number as shown in Table 2 and voucher samples were kept at the Pharmacognosy Laboratory of the Department of Pharmacy at An-Najah National University, Faculty of Medicine and Health Sciences (Table 2).

\section{Data analysis}

All citations were placed into ailment categories for each type of cancer. Factor of informant's consensus $\left(\mathrm{F}_{\mathrm{ic}}\right)$ was employed to indicate how homogenous the information is. In fact, its main use is to select disease categories where there is consensus on the use of plants among the informants. $F_{\text {ic }}$ value is close to 0 if plants are chosen randomly, or if informants do not exchange information about their use. High values of $F_{i c}$ (close to 1 ) occur when there is a well-defined selection criterion in the community and/or if information is frequently exchanged between informants [28].

The $F_{i c}$ is calculated as in the following equation:

$$
F_{i c}=\frac{N u r-N t}{N u r-1}
$$

Where Nur is the number of use citations in each category and $\mathrm{Nt}$ is the number of taxa used.

Fidelity level (Fl) was defined as the ratio between the number of informants who independently suggested the use of a species for the same major purpose and the total number of informants who mentioned the plant for any use. $\mathrm{Fl}$ is of equal importance to $\mathrm{F}_{\text {ic }}$ and it can be calculated according to the following equation:

$$
F l=\frac{N p}{N} * 100
$$

Where $\mathrm{Np}$ is the number of informants that reported a use of a plant species to treat a particular disease and $\mathrm{N}$ is the number of informants that used the plants as a medicine to treat any given disease [29].

The use-value (UV) is a quantitative method that can be used in order to prove the relative importance of species known locally. It is can be calculated according to the following equation:

$$
\mathrm{UV}-\frac{\sum U}{n}
$$

Where UV is the use value of a species; $U$ the number of citations per species; $n$ the number of informants [30].

Results of calculated $\mathrm{F}_{\mathrm{IC}}, \mathrm{Fl}$ and $\mathrm{UV}$ are shown in Tables 2, 3 and 4 . 
Table 2 Medicinal plants used for treatment of cancer in the West Bank regions/Palestine

\begin{tabular}{|c|c|c|c|c|c|c|}
\hline & $\begin{array}{l}\text { Scientific names/Common } \\
\text { names/Arabic names/Noucher } \\
\text { specimen code }\end{array}$ & Family & $\begin{array}{l}\text { Part used, method of preparation (herbal } \\
\text { formulation) and dosages }\end{array}$ & Cancer Type & $\begin{array}{l}\text { Preparation } \\
\text { method and } \\
\text { administration }\end{array}$ & UV \\
\hline 1. & $\begin{array}{l}\text { Allium cepa L./Onion / Basal/ } \\
\text { Pharm-PCT-2703 }\end{array}$ & Amaryllidaceae & $\begin{array}{l}\text { Bulb/About } 20-40 \mathrm{ml} \text { of the bulb juice is to be } \\
\text { given orally } 7-8 \text { times daily for four weeks. }\end{array}$ & $\begin{array}{l}\text { Lung and } \\
\text { stomach }\end{array}$ & $\begin{array}{l}\text { Fresh bulb } \\
\text { (oral) }\end{array}$ & 0.29 \\
\hline 2. & $\begin{array}{l}\text { Allium sativum L./ Garlic/Thom/ } \\
\text { Pharm-PCT-2704 }\end{array}$ & Amaryllidaceae & $\begin{array}{l}\text { Bulb/2-3 fresh cloves are eaten raw three times } \\
\text { daily with meals. }\end{array}$ & $\begin{array}{l}\text { Lung, } \\
\text { Esophageal } \\
\text { and breast }\end{array}$ & $\begin{array}{l}\text { Fresh bulb } \\
\text { (oral) }\end{array}$ & 0.46 \\
\hline 3. & $\begin{array}{l}\text { Mangifera indica L./ Mango/ } \\
\text { Manga/ Pharm-PCT-2725 }\end{array}$ & Anacardiaceae & $\begin{array}{l}\text { Fruits/About } 300 \mathrm{ml} \text { of fresh fruit juice is to be } \\
\text { given orally three times daily. }\end{array}$ & Colon & $\begin{array}{l}\text { Fresh juice } \\
\text { (oral) }\end{array}$ & 0.09 \\
\hline 4. & $\begin{array}{l}\text { Pistacia palaestina Boiss./ Mastic } \\
\text { tree, Lentisk/ Sirees/ Pharm-PCT- } \\
1870\end{array}$ & Anacardiaceae & $\begin{array}{l}\text { Leaves/Powdered leaves mixed with goat fat as } \\
\text { paste, applied externally twice daily on cancer area. }\end{array}$ & Skin & Paste (topical) & 0.59 \\
\hline 5. & $\begin{array}{l}\text { Annona muricata L. / Soursop/ } \\
\text { Keshta/ Pharm-PCT-2726 }\end{array}$ & Annonaceae & $\begin{array}{l}\text { Fruit/One fresh fruit boiled with } 100 \mathrm{ml} \text { syrup for } \\
\text { five minutes; } 20 \mathrm{ml} \text { of the produced syrup is to be } \\
\text { given orally three times daily. }\end{array}$ & $\begin{array}{l}\text { Bladder, } \\
\text { prostate and } \\
\text { colon }\end{array}$ & Syrup (oral) & 0.32 \\
\hline 6. & $\begin{array}{l}\text { Daucus guttatus Sm. / Wild } \\
\text { Carrot/ Jazar barry/ Pharm-PCT- } \\
832\end{array}$ & Apiaceae & $\begin{array}{l}\text { Seeds/About 100-130 powdered seeds steeped in } \\
\text { water for } 12 \text { hours; } 100 \mathrm{ml} \text { from the produced } \\
\text { infusion is to be orally given four times daily. }\end{array}$ & Skin & Infusion (oral) & 0.02 \\
\hline 7. & $\begin{array}{l}\text { Petroselinum crispum (Mill.) Fuss/ } \\
\text { Parsley/ Bokdonas/ Pharm-PCT- } \\
2739\end{array}$ & Apiaceae & $\begin{array}{l}\text { Fruits/About 500-600 grams from the ground dry } \\
\text { fruits boiled with one liter water for } 30 \text { minutes; } \\
300 \mathrm{ml} \text { of this decoction is to be given orally three } \\
\text { times daily. }\end{array}$ & $\begin{array}{l}\text { Kidney and } \\
\text { bladder }\end{array}$ & $\begin{array}{l}\text { Decoction } \\
\text { (oral) }\end{array}$ & 0.16 \\
\hline 8. & $\begin{array}{l}\text { Calotropis procera (Aiton) Dryand./ } \\
\text { Apple of Sodom, (mudar)/ A'oshar } \\
\text { basek/ Pharm-PCT-472 }\end{array}$ & Apocynaceae & $\begin{array}{l}\text { Aerial parts (latex)/ Ten grams from air dried latex } \\
\text { from the fruits is boiled with } 40 \mathrm{ml} \text { water; } 20 \mathrm{ml} \text { of } \\
\text { this decoct is to be given twice daily. }\end{array}$ & Skin & $\begin{array}{l}\text { Decoction } \\
\text { (oral) }\end{array}$ & 0.61 \\
\hline 9. & $\begin{array}{l}\text { Catharanthus roseus (L.) G.Don/ } \\
\text { Vinca/ Wanaky/ Pharm-PCT-2728 }\end{array}$ & Apocynaceae & $\begin{array}{l}\text { Entire plant/About } 25 \mathrm{grams} \text { from the powdered } \\
\text { plant mixed with } 30 \mathrm{ml} \text { water; this paste is applied } \\
\text { topically once daily. }\end{array}$ & Skin & Paste (topical) & 0.47 \\
\hline 10. & $\begin{array}{l}\text { Nerium oleander L./Oleander/ } \\
\text { Dafla/ Pharm-PCT-1636 }\end{array}$ & Apocynaceae & $\begin{array}{l}\text { Entire plant/About } 20 \text { grams from the powdered } \\
\text { plant are mixed with } 50 \text { grams lanolin; this cream } \\
\text { is applied topically on the skin cancer area directly } \\
4-5 \text { times daily. }\end{array}$ & Skin & $\begin{array}{l}\text { Cream } \\
\text { (topical) }\end{array}$ & 0.53 \\
\hline 11. & $\begin{array}{l}\text { Arum dioscoridis Sm./ Spotted } \\
\text { arum/ loof mobarkash/ Pharm- } \\
\text { PCT-243 }\end{array}$ & Araceae & $\begin{array}{l}\text { Leaves/Boil about } 10 \text { grams of the dried leaves } \\
\text { with } 100 \mathrm{ml} \text { water, fifty ml of this decoction is to } \\
\text { be given orally before meal. }\end{array}$ & $\begin{array}{l}\text { Liver and } \\
\text { stomach }\end{array}$ & $\begin{array}{l}\text { Decoction } \\
\text { (oral) }\end{array}$ & 0.66 \\
\hline 12. & $\begin{array}{l}\text { Arum palaestinum Boiss./ Cuckoo } \\
\text { pint / loof/ Pharm-PCT-246 }\end{array}$ & Araceae & $\begin{array}{l}\text { Leaves/Boil about } 10 \text { grams of the dried leaves } \\
\text { with } 150 \mathrm{ml} \text { water, fifty } \mathrm{ml} \text { of this decoction is to } \\
\text { be given orally three times daily before meals. }\end{array}$ & $\begin{array}{l}\text { Liver, colon, } \\
\text { kidney and } \\
\text { breast }\end{array}$ & $\begin{array}{l}\text { Decoction } \\
\text { (oral) }\end{array}$ & 0.63 \\
\hline
\end{tabular}

13. Polygonatum multiflorum (L.) All./ Asparagaceae Rhizomes/Steep 2 grams from the powdered David's harp / Khatem Soleyman/ Pharm-PCT-2727 rhizomes with $100 \mathrm{ml}$ water for 5 hours; $20 \mathrm{ml}$ from this infusion is to be given orally three times daily.

Liver, brain and Infusion (oral) 0.60 spinal cord

14. Brassica oleracea L./Cabbage/ malfof/ Pharm-PCT-1930

15. Sinapis arvensis L.Mild mustard/ Brassicaceae Khardal/ Pharm-PCT-2284

16. Capparis spinosa L./Caper bush/ Capparaceae Cobar/ Pharm-PCT-496

17. Colchicum hierosolymitanum L./ Colchicaceae Colchicum/Lohlah/Pharm-PCT-644

18. Achillea aleppica DC./Yarrow/ Compositae Kaysoom/ Pharm-PCT-16

Leaves $/ 100 \mathrm{ml}$ from the fresh cabbage leaf juice is to be given 7-9 times daily.

Seeds/Powdered seeds $(2 \mathrm{~g})$ given orally twice Bone

Fresh juice daily.

(oral)

Roots/Crushed fresh roots (100 grams) mixed with $10 \mathrm{ml}$ water, made into paste then applied topically once daily.

Liver

Bones cancer

Seeds/50 grams from the ground seeds mixed with Skin 100 grams lanolin a are applied topically once daily on the tumor area.

Aerial parts/Steep 15grams from the plant with $100 \mathrm{ml}$ water for 2 hours, $10 \mathrm{ml}$ from this infusion is to be given internally twice daily.

19. Cichorium endivia L./Common Compositae chicory/ Shokar/ Pharm-PCT-617
Flowers/Steep 100 grams from the plant with $100 \mathrm{ml}$ water for 2 hours; $30 \mathrm{ml}$ from this infusion is to be given once daily. 
Table 2 Medicinal plants used for treatment of cancer in the West Bank regions/Palestine (Continued)

20. Inula viscosa (L.) Aiton/False Yellow head/ Tayon/ Pharm-PCT2738

21. Matricaria aurea (Loefl.) Sch.Bip./ Golden Chamomile/Babonaj thahabi/ Pharm-PCT-1519

22. Onopordum cynarocephalum subsp./Artichoke Cotton-thistle/ kondrees/ Pharm-PCT-1692

23. Silybum marianum (L.) Gaertn./ Milk thistle Khorfeesh/Pharm-PCT2282

24. Taraxacum syriacum Boiss./ Common dandelion/Hindeba/ Pharm-PCT-2396

25. Citrullus colocynthis (L.) Schrad./ Bitter Gourd/Hanthal/Pharm-PCT628

26. Cucumis sativus L./cucumber/ kheyar/ Pharm-PCT-2737

27. Ecballium elaterium (L.) A.Rich./ Exploding cucumber / Ketha' alhemar/ Pharm-PCT-870

28. Ephedra alata Decne./ Ephedra/ Alanda/ Pharm-PCT-904

29. Arbutus andrachne L./Greek Strawberry Tree/ Kotlob/ PharmPCT-213

30. Euphorbia hierosolymitana Boiss./ Spurge/Halablabon/Pharm-PCT988

31. Quercus calliprinos Webb/ Palestine oak/ Baloot/ Pharm-PCT1978

32. Quercus ithaburensis Decne./ Valonia oak/Sendnyan/ PharmPCT-1980

33. Hypericum perforatum L./St.John's Wort/ Oshbat ala'ran/Pharm-PCT2734

34. Crocus sativus L./ Saffron/ Za'faran/ Pharm-PCT-2733

35. Melissa officinalis L./Balm mint/ Torenjan/ Pharm-PCT-1564

36. Origanum jordanicum Danin \& Kunne/Thyme/Za'atar/Pharm-PCT1729
Compositae

Leaves/ Boil about 20 grams from the flowers with $100 \mathrm{ml}$ water; $30 \mathrm{ml}$ of this decoction is to be given orally three times daily before meals.

Compositae

Flowers/ In case of lung cancer: Boil 50 grams flowers with $500 \mathrm{ml}$ water; the vapor is inhaled twice daily for 10 minutes each time.In case of liver and prostate cancers: Boil 30 grams from the flowers with $300 \mathrm{ml}$ water for 15 minutes; $100 \mathrm{ml}$ from the decoction is to be given orally twice daily.

Compositae

Flowers/ Steep 50 grams of the dried flowers with $100 \mathrm{ml}$ water for one night; $50 \mathrm{ml}$ from this infusion is to be given three times daily.

Compositae Stalk/ 30 drops of celery stalk fresh juice is to be given orally every three hours.

Compositae

Leaves/ Boil about 60 grams from the dried powdered plant with $100 \mathrm{ml}$ water for 15 minutes; entire decoction is to be given 3-5 times daily.

Cucurbitaceae

Fruits/ About 150 grams from the powdered dried fruits mixed with equal quantity of lanolin; the produced cream applied topically twice daily.

Cucurbitaceae Seeds/ Steep 4grams of the ground seeds with $100 \mathrm{ml}$ water for 12 hours; $10 \mathrm{ml}$ from this infusion is to be given three times daily

Cucurbitaceae

Fruits (juice)/ / One fresh fruit pulp (about 25gram) juice is to be orally given five times daily

Ephedraceae

Entire plant/ About 100 grams of the powdered plant boiled with $500 \mathrm{ml}$ water for 5 minutes; $100 \mathrm{ml}$ of this decoction is to be given orally twice a day.

Ericaceae

Fruits/ Boil 50 grams of the ground fruits with $100 \mathrm{ml}$ water and 100 gram sugar; $20 \mathrm{ml}$ of the produced syrup is to be given orally $5-6$ times daily.

Euphorbiaceae Entire plant/ Boil 50 grams from the plant with $150 \mathrm{ml}$ water for 10 minutes; $5 \mathrm{ml}$ of this decoction is to be given each 8 hours.

Fagaceae

Fruits/ Boil about 20 grams from the fruits with $100 \mathrm{ml}$ water, $20 \mathrm{ml}$ of this decoction is to be given four times daily.

Fagaceae

Bark/ Mix 30 grams of the powdered bark with $100 \mathrm{ml}$ lanolin then apply this cream on the cancer area.

Hypericaceae

Flowers/ About 100 grams of the powdered flowers with $100 \mathrm{ml}$ olive oil then filtered and $20 \mathrm{ml}$ of the produced infusion is to be given orally twice daily.

Iridaceae

Flowers/ Two grams of Saffron powder steeped in $300 \mathrm{ml}$ camel milk; this milk infusion is to be given early morning once daily.

Lamiaceae

Aerial parts/ About 10 grams of the fresh leaves are given orally five times daily.

Leaves/ About 50 grams of the leaves boiled in $500 \mathrm{ml}$ water; inhale vapor three times daily, five minutes each time.

$\begin{array}{lll}\begin{array}{l}\text { Kidney and } \\ \text { bladder }\end{array} & \begin{array}{l}\text { Decoction } \\ \text { (oral) }\end{array} & 0.32 \\ & & \\ \text { Lung, liver and } & \begin{array}{l}\text { Vapor } \\ \text { prostate }\end{array} & 0.47 \\ & \text { inhalation } & \end{array}$

Stomach and Infusion (oral) 0.23 colon

Colon and skin Fresh juice

cancer (oral)

Pancreatic and Decoction

gallader

stomach

Skin Cream

(topical)

Colon

Infusion (oral)

Throat and Fresh juice

liver (oral)

Brain, liver and Decoction

colon (oral)

Stomach

Syrup (oral)

Ovarian, breast Decoction

and prostate (oral)

Colorectal Decoction

(oral)

$\begin{array}{ll}\text { Skin } & \begin{array}{l}\text { Cream } \\ \text { (topical) }\end{array}\end{array}$

Brain

Infused in olive oil (oral)

Liver and

Infusion (oral) 0.46

kidney

Lung and non- Fresh plant

Hodgkin (oral)

lymphoma

Lung, throat

Vapor cancer inhalation

2

7


Table 2 Medicinal plants used for treatment of cancer in the West Bank regions/Palestine (Continued)

37. Rosmarinus officinalis $L /$ Rosemary/ Hasa alban/ PharmPCT-2732

38. Salvia fruticosa Mill./ Sage/ Maryamya/ Pharm-PCT-2117

39. Salvia palaestina Benth./ Kosa'en(kharna) falestini/ PharmPCT-2124

40. Teucrium capitatum L./ Teucrium/ Lamiaceae Ja'da/ Pharm-PCT-2407

41. Laurus nobilis L. / Bay/ Gaar/ Pharm-PCT-1366

Lauraceae

Alhagi graecorum Boiss./Camelthorn/ ala'alook/ Pharm-PCT-65

Leguminosae

43. Glycine soja Siebold \& Zucc./ Soy/ Leguminosae Soya/ Pharm-PCT-2731

44. Ononis viscosa subsp. sicula (Guss.) Leguminosae Hub.-Mor./ spiny restharrow/ Shabrak(wassem)/ Pharm-PCT1686

45. Linum usitatissimum L./ Flax/ Linaceae Ketan/ Pharm-PCT-2735

46. Lawsonia inermis L./ Henna / Lythraceae Hena/ Pharm-PCT-2736

47. Punica granatum L./ Pomegranate/ Romman/ PharmLythraceae PCT-2730

48. Ficus sycomorus L./ Sycamore Fig / Moraceae Jomeez/ Pharm-PCT-1030

49. Psidium guajava L./ Guava /Juafa/ Myrtaceae Pharm-PCT-2720

50. Orobanche aegyptiaca Pers. / Broomrape/ Halook/ Pharm-PCT1746

51. Trifolium philistaeum var. filifolium Papilionaceae Zohary/ Palestine Clover/ Barsem/ Pharm-PCT-2493

52. Plantago lanceolata L./ narrowleaf Plantaginaceae plantain/ Lesan alhamal/ PharmPCT-1887

53. Triticum aestivum L./ Bread wheat/ Poaceae Kameh/ Pharm-PCT-2540

54. Portulaca oleracea L./ Little Hogweed/ Farfahena/ Pharm-PCT1935

55. Cyclamen persicum Mill./ Cyclamen/ Sapoon alraa'e/ Pharm-PCT-777

56. Nigella arvensis L./ Black cumin / Ranunculaceae Kezha/ Pharm-PCT-1640

Orobanchaceae

Portulacaceae

Primulaceae
Leaves/ About 20 grams of the leaves boiled in $600 \mathrm{ml}$ water; inhale vapor three times daily, about ten minutes each time.

Aerial parts/ Boil about 70 grams from the leaves with $300 \mathrm{ml}$ water, the decoction is to be given four times daily.

Leaves/ Fifteen grams of the leaves steeped with $100 \mathrm{ml}$ water for 12 hours; $10 \mathrm{ml}$ from this infusion is to be given twice a day.

Entire plant/ About 150 grams of the plant boiled for 10 minutes with water; $30 \mathrm{ml}$ from the produced decoction is to be given once daily.

Leaves/ Ten grams from the dried leaves boiled with $100 \mathrm{ml}$ water; $20 \mathrm{ml}$ of this decoction is to be given before meals 3-4 times daily

Fruits/ About 50 grams from the dried fruits boiled in $300 \mathrm{ml}$ water; $10 \mathrm{ml}$ of this decoction is to be given orally twice daily.

Seeds/ About 100 grams of the seeds boiled in $500 \mathrm{ml}$ water; $100 \mathrm{ml}$ of this decoction is to be given orally 5-7 times daily.

Entire plant/ About 20-30 grams from the powdered plant boiled in $350 \mathrm{ml}$ water; $10 \mathrm{ml}$ of this decoction is to be given twice daily.

Seeds/ Ground Seed (10 grams) are to be given orally three times daily.

Leaves/ A paste from crushed fresh leaves (about 30 grams) are applied externally to affected areas.

Fruits (peels)/ About 500 grams of the fruit peels boiled in 1 liter water with 1000 grams sugar; $50 \mathrm{ml}$ of this syrup is to be given twice daily.

Fruits/ One fresh fruit is boiled with $100 \mathrm{ml}$ syrup for five minute; $20 \mathrm{ml}$ of the syrup is to be given orally 4-6 times daily.

Leaves/ A decoction of 100 grams leaves is prepared in one liter water; 2-3 cups are taken orally per day until improvement occurs.

Roots/ About 500 grams of the ground roots boiled in one liter water for 30 minutes, $50 \mathrm{ml}$ of this decoction is to be given orally once daily.

Flowers/ About 50 grams of the flowers boiled in $60 \mathrm{ml}$ water; $30 \mathrm{ml}$ of this decoction is to be taken internally twice a day.

Leaves/ About 500 grams of the leaves boiled in $500 \mathrm{ml}$ water; $100 \mathrm{ml}$ of this decoction is to be taken internally 3-5 times a day.

Seeds (husk)/ Powdered seed husks (10 grams) are given orally three times daily.

Aerial parts/ About 100 grams of the plant boiled in $500 \mathrm{ml}$ water; $30 \mathrm{ml}$ of this decoction is to be taken 3-5 times a day.

Roots/ Twenty five grams of the ground roots boiled in $350 \mathrm{ml}$ water; $30 \mathrm{ml}$ of this decoction is to be given orally twice daily.

Seeds/ About 100 grams of the ground seeds boiled in $330 \mathrm{ml}$ water for 10-15 minutes; this decoction is to be taken $4-5$ times daily

\begin{tabular}{|c|c|c|}
\hline Lung cancer & $\begin{array}{l}\text { Vapor } \\
\text { inhalation }\end{array}$ & 0.10 \\
\hline Colon and liver & $\begin{array}{l}\text { Decoction } \\
\text { (oral) }\end{array}$ & 0.26 \\
\hline Brain & Infusion (oral) & 0.19 \\
\hline $\begin{array}{l}\text { Pancreatic and } \\
\text { liver }\end{array}$ & $\begin{array}{l}\text { Decoction } \\
\text { (oral) }\end{array}$ & 0.42 \\
\hline Prostate & $\begin{array}{l}\text { Decoction } \\
\text { (oral) }\end{array}$ & 0.25 \\
\hline Glandular & $\begin{array}{l}\text { Decoction } \\
\text { (oral) }\end{array}$ & 0.13 \\
\hline $\begin{array}{l}\text { Breast, ovarian } \\
\text { and Hodgkin } \\
\text { lymphoma }\end{array}$ & $\begin{array}{l}\text { Decoction } \\
\text { (oral) }\end{array}$ & 01 \\
\hline $\begin{array}{l}\text { Prostate, } \\
\text { stomach and } \\
\text { breast }\end{array}$ & $\begin{array}{l}\text { Decoction } \\
\text { (oral) }\end{array}$ & 0.07 \\
\hline $\begin{array}{l}\text { Ovarian, breast } \\
\text { and colon }\end{array}$ & Powder (oral) & 0.19 \\
\hline Skin & Paste (topical) & 0.22 \\
\hline Colorectal & Syrup (oral) & 027 \\
\hline Lung & Syrup (oral) & \\
\hline
\end{tabular}

Lung and Decoction

stomach (oral)

Ovarian and Decoction

breast (oral)

Ovarian, breast Decoction

and non $\quad$ (oral)

Hodgkin

lymphoma

Throat

Decoction

(oral)

Powder (oral)

Stomach and

Decoction

(oral)

Prostate and Decoction

(oral)

Lung, brain

Decoction and skin 
Table 2 Medicinal plants used for treatment of cancer in the West Bank regions/Palestine (Continued)

\begin{tabular}{|c|c|c|c|c|c|c|}
\hline 57. & $\begin{array}{l}\text { Ziziphus spina-christi (L.)Desf./ } \\
\text { Christ's Thorn Jujube/ Cedar/ } \\
\text { Pharm-PCT-2693 }\end{array}$ & Rhamnaceae & $\begin{array}{l}\text { Flowers/ About } 100 \text { grams of the flowers boiled in } \\
500 \mathrm{ml} \text { water; } 50 \mathrm{ml} \text { of this decoction is to be } \\
\text { given internally } 4-7 \text { times daily. }\end{array}$ & Lung & $\begin{array}{l}\text { Decoction } \\
\text { (oral) }\end{array}$ & 0.31 \\
\hline 58. & $\begin{array}{l}\text { Crataegus azarolus L./ Azarole } \\
\text { Hawthorn/ Za'ror/ Pharm-PCT-712 }\end{array}$ & Rosaceae & $\begin{array}{l}\text { Fruits/ One kilogram of fresh fruit boiled with } \\
1000 \mathrm{ml} \text { syrup for } 30 \text { minute; } 50 \mathrm{ml} \text { of the syrup is } \\
\text { to be given 5-6 times per day. }\end{array}$ & Lung & Syrup (oral) & 0.41 \\
\hline 59. & $\begin{array}{l}\text { Galium aparine L./ Stickyweed/ } \\
\text { Satoor/ Pharm-PCT-1069 }\end{array}$ & Rubiaceae & $\begin{array}{l}\text { Leaves/ Fifty grams of the leaves steeped with } \\
100 \mathrm{ml} \text { water for one night; } 10 \mathrm{ml} \text { from this } \\
\text { infusion is to be given twice daily. }\end{array}$ & $\begin{array}{l}\text { Hodgkin } \\
\text { Lymphoma }\end{array}$ & Infusion (oral) & 0.11 \\
\hline 60. & $\begin{array}{l}\text { Salix alba L./ White Salix/ Sofsaf } \\
\text { abyad/ Pharm-PCT-2093 }\end{array}$ & Salicaceae & $\begin{array}{l}\text { Bark/ About } 60 \text { grams from the plant boiled with } \\
500 \mathrm{ml} \text { water for } 10 \text { minutes; } 50 \mathrm{ml} \text { of this } \\
\text { decoction is to be given orally each } 6 \text { hours. }\end{array}$ & Colon & $\begin{array}{l}\text { Decoction } \\
\text { (oral) }\end{array}$ & 0.19 \\
\hline 61. & $\begin{array}{l}\text { Viscum cruciatum Sieber ex Boiss./ } \\
\text { Mistletoe/ hedal/ Pharm-PCT-2662 }\end{array}$ & Santalaceae & $\begin{array}{l}\text { Leaves/ About } 500 \text { grams from the powdered } \\
\text { plant boiled with one liter water for } 10 \text { minutes; } 50 \\
\text { drops of this decoction is to be given three times } \\
\text { daily. }\end{array}$ & Esophageal & $\begin{array}{l}\text { Decoction } \\
\text { (oral) }\end{array}$ & 0.51 \\
\hline 62. & $\begin{array}{l}\text { Acer obtusifolium Sm./ Syrian } \\
\text { Maple/ Kaikab/ Pharm-PCT-15 }\end{array}$ & Sapindaceae & $\begin{array}{l}\text { Fruits/ About } 500 \text { grams of the fresh fruits boiled } \\
\text { with } 100 \mathrm{ml} \text { water and } 100 \text { gram sugar; } 20 \mathrm{ml} \text { of } \\
\text { the resulting syrup is to be given } 6-8 \text { times per } \\
\text { day. }\end{array}$ & $\begin{array}{l}\text { Throat and } \\
\text { lung }\end{array}$ & Syrup (oral) & 0.21 \\
\hline 63. & $\begin{array}{l}\text { Verbascum sinuatum L./ Mullein/ } \\
\text { A'awarwar/ Pharm-PCT-2604 }\end{array}$ & Scrophulariaceae & $\begin{array}{l}\text { Leaves/ Five grams of the leaves boiled with } \\
150 \mathrm{ml} \text { water for } 30 \text { minutes; } 15 \mathrm{ml} \text { of this } \\
\text { decoction is to be given orally twice daily. }\end{array}$ & Breast & $\begin{array}{l}\text { Decoction } \\
\text { (oral) }\end{array}$ & 0.59 \\
\hline 64. & $\begin{array}{l}\text { Capsicum annuum L/ Chili } \\
\text { pepper/ Shatta/ Pharm-PCT-2729 }\end{array}$ & Solanaceae & $\begin{array}{l}\text { Fruits/ Four fruits ( } 100 \text { grams) from the plant boiled } \\
\text { with } 200 \mathrm{ml} \text { water for } 20 \text { minutes; } 5 \text { drops of this } \\
\text { decoction is to be given orally each } 8 \text { hours. }\end{array}$ & Skin, bladder & $\begin{array}{l}\text { Decoction } \\
\text { (oral) }\end{array}$ & 0.16 \\
\hline 65. & $\begin{array}{l}\text { Lycium europaeum L./ Box thorn/ } \\
\text { A'wsaj/ Pharm-PCT-1487 }\end{array}$ & Solanaceae & $\begin{array}{l}\text { Fruit/ About half kilogram from the fruit boiled } \\
\text { with } 500 \mathrm{ml} \text { water for one hour; } 50 \mathrm{ml} \text { of this } \\
\text { decoction is to be given once daily. }\end{array}$ & $\begin{array}{l}\text { Bladder, } \\
\text { prostate and } \\
\text { breast }\end{array}$ & $\begin{array}{l}\text { Decoction } \\
\text { (oral) }\end{array}$ & 0.37 \\
\hline 66. & $\begin{array}{l}\text { Mandragora autumnalis Mill./ } \\
\text { Mandrake/ Tofah almajan/ Pharm- } \\
\text { PCT-1509 }\end{array}$ & Solanaceae & $\begin{array}{l}\text { Fruits/ Ten grams from the plant boiled with } 100 \mathrm{ml} \\
\text { water for } 30 \text { minutes, } 5 \text { drops of this decoction is } \\
\text { to be given twice daily. }\end{array}$ & Lung & $\begin{array}{l}\text { Decoction } \\
\text { (oral) }\end{array}$ & 0.21 \\
\hline 67. & $\begin{array}{l}\text { Withania somnifera (L.) Dunal/ } \\
\text { Ashwagandha/ A'eba'b } \\
\text { monawem/ Pharm-PCT-2678 }\end{array}$ & Solanaceae & $\begin{array}{l}\text { Roots/ About } 50 \text { grams of the ground roots } \\
\text { steeped with } 100 \mathrm{ml} \text { water for } 24 \text { hours; } 10 \mathrm{ml} \\
\text { from this infusion is to be given twice daily. }\end{array}$ & $\begin{array}{l}\text { Esophageal, } \\
\text { skin and } \\
\text { prostate }\end{array}$ & Infusion (oral) & 0.19 \\
\hline 68. & $\begin{array}{l}\text { Camellia sinensis (L.) Kuntze } \\
\text { /Green Tea/ Shae akhdar/ Pharm- } \\
\text { PCT-2706 }\end{array}$ & Theaceae & $\begin{array}{l}\text { Leaves/ About } 50 \text { grams from the plant boiled } \\
\text { with } 300 \mathrm{ml} \text { water for } 10 \text { minutes; this decoction is } \\
\text { to be given } 6-8 \text { times daily. }\end{array}$ & $\begin{array}{l}\text { Breast, lung } \\
\text { and ovarian }\end{array}$ & $\begin{array}{l}\text { Decoction } \\
\text { (oral) }\end{array}$ & 0.31 \\
\hline 69. & $\begin{array}{l}\text { Daphne linearifolia L./ Mezereon/ } \\
\text { Mazeryon/ Pharm-PCT-825 }\end{array}$ & Thymelaeaceae & $\begin{array}{l}\text { Fruits/ A decoction is prepared from } 7 \text { to } 8 \text { fruits } \\
\text { (about } 100 \text { grams) boiled in } 1 \text { liter water and taken } \\
\text { orally, } 1 \mathrm{ml} \text { two times per day and taken for } \\
14 \text { days. }\end{array}$ & Lung & $\begin{array}{l}\text { Decoction } \\
\text { (oral) }\end{array}$ & 0.04 \\
\hline 70. & $\begin{array}{l}\text { Urtica urens L./ Small Nettle/ } \\
\text { Korees harek/ Pharm-PCT-2562 }\end{array}$ & Urticaceae & $\begin{array}{l}\text { Aerial parts/ About 100-120 grams of the plant } \\
\text { boiled with } 500 \mathrm{ml} \text { water for } 30 \text { minutes; } 50 \mathrm{ml} \text { of } \\
\text { the decoction is to be given three times daily. }\end{array}$ & $\begin{array}{l}\text { Bones and } \\
\text { stomach }\end{array}$ & $\begin{array}{l}\text { Decoction } \\
\text { (oral) }\end{array}$ & 0.51 \\
\hline 71. & $\begin{array}{l}\text { Curcuma longa L./ Turmeric/ } \\
\text { Korkom/ Pharm-PCT-2709 }\end{array}$ & Zingiberaceae & $\begin{array}{l}\text { Rhizomes/ About } 500 \text { grams from the ground dry } \\
\text { rhizomes boiled with one liter water for } \\
30 \text { minutes; } 300 \mathrm{ml} \text { of this decoction is to be given } \\
\text { orally three times daily. }\end{array}$ & $\begin{array}{l}\text { Prostate, } \\
\text { bladder and } \\
\text { liver }\end{array}$ & $\begin{array}{l}\text { Decoction } \\
\text { (oral) }\end{array}$ & 0.53 \\
\hline 72. & $\begin{array}{l}\text { Zingiber officinale Roscoe/ Ginger/ } \\
\text { Zangabil/ Pharm-PCT-2724 }\end{array}$ & Zingiberaceae & $\begin{array}{l}\text { Rhizomes/ About } 100 \text { grams of the ground dry } \\
\text { rhizomes are boiled in } 300 \mathrm{ml} \text { water for } 10 \text { minutes } \\
\text { and given twice daily after meals. }\end{array}$ & $\begin{array}{l}\text { Stomach and } \\
\text { liver }\end{array}$ & Infusion (oral) & 0.51 \\
\hline
\end{tabular}

\section{Results and discussion}

Traditional herbal medicine knowledge and their utilization by indigenous cultures are not only useful for conservation of biodiversity and cultural traditions but also useful for the population's healthcare and drug discovery in the present and in the future [31, 32].
Several studies have shown that around $80 \%$ of rural populations in the developing countries consider herbal remedies as integral parts of treatments available. Recently, the use of natural herbal products is increasing in both developed and developing countries due to many reasons $[33,34]$. 
Table 3 Factor of informant's consensus $\left(F_{i c}\right)$ categorized by the types of cancer

\begin{tabular}{lllll}
\hline & Types of cancer & $\mathrm{Nt}$ & $\mathrm{Nur}$ & $\mathrm{F}_{\mathrm{ic}}$ \\
\hline 1 & Lung & 15 & 350 & 0.96 \\
2 & Colorectal & 14 & 345 & 0.96 \\
3 & Liver & 13 & 364 & 0.97 \\
4 & Skin & 13 & 564 & 0.98 \\
5 & Stomach & 11 & 265 & 0.96 \\
6 & Breast & 11 & 267 & 0.96 \\
7 & Prostate & 9 & 172 & 0.95 \\
8 & Bladder & 8 & 159 & 0.96 \\
9 & Ovarian & 6 & 84 & 0.94 \\
10 & Brain & 5 & 122 & 0.97 \\
11 & Throat & 4 & 74 & 0.96 \\
12 & Kidney & 4 & 96 & 0.97 \\
13 & Esophageal & 4 & 157 & 0.98 \\
14 & Bone & 3 & 194 & 0.99 \\
15 & Hodgkin's lymphoma & 2 & 19 & 0.94 \\
16 & Non-Hodgkin's lymphoma & 2 & 25 & 0.96 \\
17 & Pancreatic & 2 & 57 & 0.98 \\
18 & Spinal cord & 1 & 25 & 1 \\
19 & Gallbladder & 1 & 24 & 1 \\
\hline
\end{tabular}

As shown in (Table 1), most of the respondents who work in this field were males. Most of them had educational level equal or higher than high school. In fact about $19.3 \%$ of the total interviewed were university graduates. The table also showed that the majority of respondents were from areas of the West Bank that mostly depend on agriculture or grazing as a mean of income (Jenin, Nablus, Salfeit and Toulkarem). In fact these areas are geographically close to each other (Fig. 1).

Notably the results of this research have revealed that 72 plant species belonging to 44 families were frequently used for treatment of cancer by the 150 herbalists, traditional practitioner healers, rural dwellers and people of the West Bank, Palestine (Table 2).

Echoing our findings in this research, members of the family Compositae and Lamiaceae were the most commonly used as presented in Table 2. The methods of preparation were decoctions (boiling the plants parts in water), infusions (steeping the plants in water for limited time), syrup (boiling the plants with water and sugar $(1: 1)$, creams (mixing the plant powders with goat fat or lanolin), paste, fresh juice, ingested entire plant, powder and vapor inhalations. Decoctions and infusions were the most frequently used methods of preparation as presented in Fig. 2.

Leaves, fruits and seeds were reported to be the most frequently used parts of plants for the treatment of cancer, constituting about $56.9 \%$ of the preparations. This was followed by flowers, aerial parts, entire plants, roots, rhizomes, barks, bulb and stalks as presented in Fig. 3.

The most common cancer type treated with herbal remedies was lung cancer followed by liver, skin, colon and breast cancers as reported in (Fig. 4).

This research shows that the medicinal plants still play a role in the care of cancer patients in Palestine. Ephedra alata, Arum dioscoridis, Arum palaestinum were the most commonly used medicinal plants for treatment of cancer and all of these three plants were prepared as decoctions.

However, Ephedra alata were reported to treat three different types of cancer (brain, liver and colon). Accordingly, three $\mathrm{Fl}$ values were calculated. The highest one (40.74 \%) was for liver cancer. The same consideration can be raised for Arum palaestinum which was reported to treat four different cancers (Liver, colon, kidney and breast). Breast cancer showed the highest $\mathrm{Fl}$ value (45.74\%). According to table 4, only $\mathrm{Fl}$ values higher than $50 \%$ were included.

In the Mediterranean region and especially in the Holy land (Palestine), the traditional medicine has been highly appreciated and trusted. Many patients go to herbalists or informants to get benefit from this field. Most practitioners are males and this was confirmed in this study; some of them have university degrees. Complementary and alternative medicines are widely used among cancer patients throughout the world. In a previous study from Palestine, $60.9 \%$ of cancer patients reported using medicinal herbs [35]. Medicinal plants utilized in indigenous health traditional system are gradually becoming wiped out due to over utilization, human overpopulation and from other human impact on the environment. The main problem is destructive harvesting of the subterranean parts of the medicinal plants, or even the entire plant.

Medicinal plants maintain the health and vitality of individuals, and may help in treatment of various diseases, including cancer. In this study, some anticancer medicinal plants of foreign origin have been presented. Many of these medicinal plants possess good immunomodulatory and antioxidant properties, which may lead to anticancer activities. The antioxidant phytochemicals protect the cells from oxidative damage. Thus, consuming a diet rich in antioxidant plant foods (e.g. fruits and vegetables) will provide health-protective effects. In 2013, a traditional practitioner living in Jenin claimed that he could cure a cancer patient completely using Ephedra alata. The local media here were interested in this story and many researchers have started working on this plant.

A multidisciplinary approach combining traditional herbal knowledge with pharmaceutical research is a 
Table 4 Fidelity level of herbal medicines mentioned

\begin{tabular}{|c|c|c|c|c|}
\hline Medicinal plant & Type of cancer & $\mathrm{Np}$ & $\mathrm{N}$ & $\mathrm{FL}, \%$ \\
\hline Achillea aleppica DC. & Colon & 13 & 13 & 100.00 \\
\hline Alhagi graecorum Boiss. & Skin & 88 & 88 & 100.00 \\
\hline Arbutus andrachne $\mathrm{L}$. & Skin & 3 & 3 & 100.00 \\
\hline Brassica oleracea L. & Skin & 91 & 91 & 100.00 \\
\hline Calotropis procera (Aiton) Dryand. & Skin & 70 & 70 & 100.00 \\
\hline Capparis spinosa L. & Skin & 79 & 79 & 100.00 \\
\hline Catharanthus roseus (L.) G.Don & Liver & 69 & 69 & 100.00 \\
\hline Citrullus colocynthis (L.) Schrad. & Bone & 71 & 71 & 100.00 \\
\hline Colchicum hierosolymitanum L. & Bones cancer & 71 & 71 & 100.00 \\
\hline Crataegus azarolus L. & Skin & 79 & 79 & 100.00 \\
\hline Cucumis sativus $\mathrm{L}$. & Liver & 16 & 16 & 100.00 \\
\hline Daphne linearifolia L. & Skin & 19 & 19 & 100.00 \\
\hline Daucus guttatus Sm. & Colon & 10 & 10 & 100.00 \\
\hline Ficus sycomorus L. & Stomach & 9 & 9 & 100.00 \\
\hline Galium aparine L. & Colorectal & 17 & 17 & 100.00 \\
\hline Hypericum perforatum L. & Skin & 20 & 20 & 100.00 \\
\hline Laurus nobilis L. & Brain & 8 & 8 & 100.00 \\
\hline Lawsonia inermis L. & Lung & 15 & 15 & 100.00 \\
\hline Mandragora officinalis Mill. & Brain & 28 & 28 & 100.00 \\
\hline Mangifera indica $\mathrm{L}$. & Prostate & 37 & 37 & 100.00 \\
\hline Nerium oleander $\mathrm{L}$. & Glandular & 19 & 19 & 100.00 \\
\hline Pistacia palaestina Boiss. & Skin & 33 & 33 & 100.00 \\
\hline Plantago lanceolata $\mathrm{L}$. & Colorectal & 40 & 40 & 100.00 \\
\hline Punica granatum L. & Lung & 29 & 29 & 100.00 \\
\hline Quercus calliprinos Webb & Throat & 43 & 43 & 100.00 \\
\hline Quercus ithaburensis Decne. & Colon & 66 & 66 & 100.00 \\
\hline Rosmarinus officinalis $\mathrm{L}$. & Lung & 47 & 47 & 100.00 \\
\hline Salix alba L. & Lung & 61 & 61 & 100.00 \\
\hline Salvia palaestina Benth. & Hodgkin's Lymphoma & 16 & 16 & 100.00 \\
\hline Sinapis arvensis $\mathrm{L}$. & Colon & 29 & 29 & 100.00 \\
\hline Triticum aestivum L. & Esophageal & 77 & 77 & 100.00 \\
\hline Verbascum sinuatum $\mathrm{L}$. & Breast & 89 & 89 & 100.00 \\
\hline Viscum cruciatum Sieber ex Boiss. & Lung & 31 & 31 & 100.00 \\
\hline Ziziphus spina-christi (L.)Desf. & Lung & 6 & 6 & 100.00 \\
\hline Origanum jordanicum Danin \& Kunne & Lung & 18 & 23 & 78.26 \\
\hline Psidium guajava $\mathrm{L}$. & Lung & 21 & 29 & 72.41 \\
\hline Orobanche aegyptiaca Pers. & Breast & 23 & 32 & 71.88 \\
\hline Urtica urens $\mathrm{L}$. & Bones & 52 & 77 & 67.53 \\
\hline Zingiber officinale Roscoe & Stomach & 52 & 77 & 67.53 \\
\hline Arum dioscoridis Sm. & Stomach & 99 & 99 & 66.67 \\
\hline Allium cepa L. & Stomach & 29 & 44 & 65.91 \\
\hline Teucrium capitatum L. & Pancreatic & 41 & 63 & 65.08 \\
\hline Portulaca oleracea L. & Esophageal & 42 & 71 & 59.15 \\
\hline Salvia fruticosa Mill. & Colon & 23 & 39 & 58.97 \\
\hline
\end{tabular}


Table 4 Fidelity level of herbal medicines mentioned (Continued)

\begin{tabular}{|c|c|c|c|c|}
\hline Melissa officinalis $L$. & Non-Hodgkin's lymphoma & 24 & 41 & 58.54 \\
\hline Inula viscosa (L.) Aiton & Kidney & 28 & 48 & 58.33 \\
\hline Crocus sativus L. & Kidney & 39 & 69 & 56.52 \\
\hline Acer obtusifolium Sm. & Lung & 18 & 32 & 56.25 \\
\hline Onopordum cynarocephalum subsp. & Colon & 19 & 34 & 55.88 \\
\hline Petroselinum crispum (Mill.) Fuss & Kidney & 13 & 24 & 54.17 \\
\hline Capsicum annuum L & Bladder & 13 & 24 & 54.17 \\
\hline Trifolium philistaeum var. filifolium Zohary & Ovarian & 11 & 21 & 52.38 \\
\hline Annona muricata $\mathrm{L}$. & Bladder & 25 & 48 & 52.08 \\
\hline Ecballium elaterium (L.) A.Rich. & Liver & 13 & 25 & 52.00 \\
\hline Glycine soja Siebold \& Zucc. & Ovarian & 15 & 29 & 51.72 \\
\hline Cyclamen persicum Mill. & Bladder & 16 & 31 & 51 \\
\hline Cichorium endivia $\mathrm{L}$. & Colon & 17 & 33 & 51.52 \\
\hline Curcuma longa $\mathrm{L}$. & Bladder & 41 & 80 & \\
\hline
\end{tabular}

valuable method for identifying potential herbs with possible clinical significance in cancer care [36].

To achieve a positive response to herbal preparations, the proper part of the plant that contains the active constituents should be chosen. It is well known that not all the plant parts contain the same concentration of the active constituents. The other factors to be considered are the harvesting time of the herb (collection time), the soil, the climate conditions, and the method of drying, processing, and extraction [37, 38]. Methods of preparation were mainly decoction and infusion. This is similar to previous studies in our country conducted by AliShtayeh et al., 2011 and Jaradat, 2005 [35, 39]. In an ethnopharmacological survey of medicinal herbs in Golan Heights and the West Bank region performed by Said et al., 2002, only seven plant species were found to treat cancer among 81 species used for treating 115 different ailments and diseases [40]. In another study conducted in the West Bank, Ali-Shtayeh and Rana, 2011, found only 25 plant species used for treatment in cancer without mentioning which type of cancer they can treat [41].

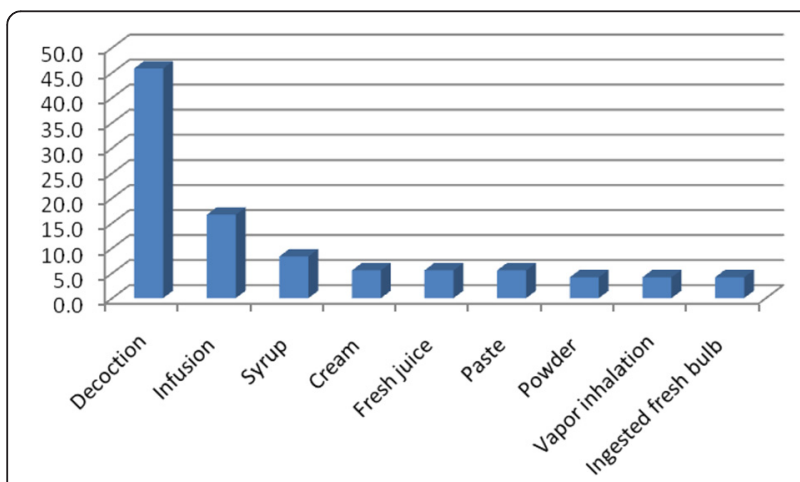

Fig. 2 Frequency of methods of preparation from herbals
In another study conducted by Ali-Shtayeh et al., 2011, in Palestine, 58 plant species were collected for cancer treatments [35], while in the survey which was conducted by Hudaib et al., 2008 in Jordan, Mujib Nature Reserve and surrounding area, only six plant species were found for treatment of cancer also without mentioning the type of cancer [42].

The methods of preparation mentioned by the informants are not supported by scientific evidence; this could be suitable for some plants but not for the others. In fact, the boiling process can cause severe degradation of the medicinal components in some plants.

The dosage is another concern. To have the expected benefits, the patients should receive a fixed well defined dosage, but in traditional medicine the suitable doses are not clear [37], so studies are needed to determine the concentration of active ingredients depending on their method of preparation to give the suitable recommended doses.

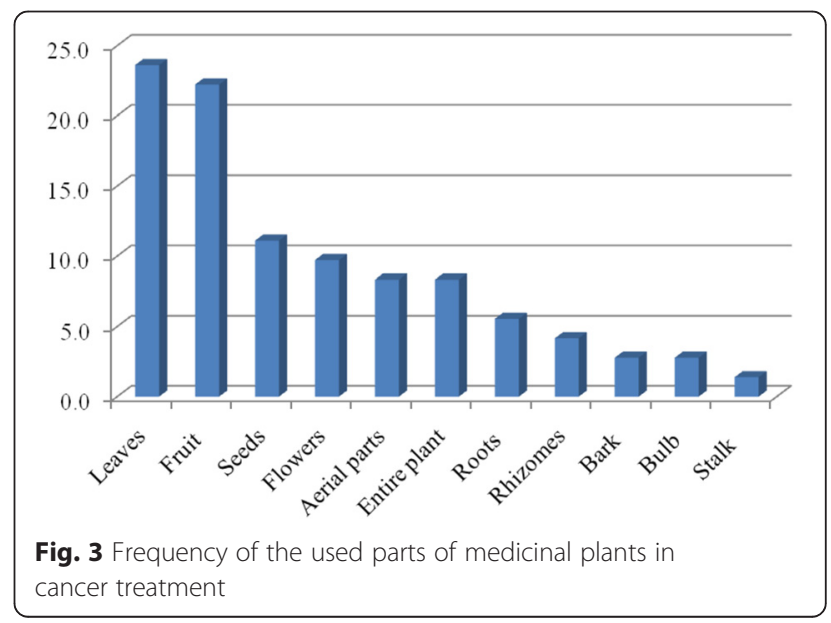




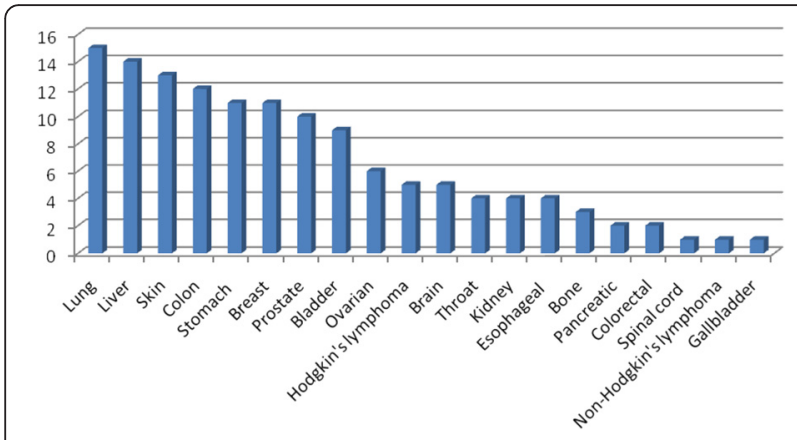

Fig. 4 Cancer types treated with herbals in Palestine

Table 3 shows the $F_{\text {ic }}$ values calculated for the categorized cancers. $F_{i c}$ values obtained for the reported cancers indicate the degree of shared knowledge among informants for the treatment of a cancer by certain medicinal plants. Most cancers had high $\mathrm{F}_{\text {ic }}$ values; however the highest $\mathrm{F}_{\mathrm{ic}}=1$ was scored for spinal cord and gallbladder cancers. $\mathrm{Fl}$ was $100 \%$ for many plants; the highest UV (0.72) was for Ephedra alata.

Most of the mentioned plants in Table 2 are edible plants and the most of the non-edible plants were used externally. Therefore minor restrictions could be included as they have minor risk compared to the obtained therapeutic benefits from their use for cancer.

Resulting from this information, scientific practical work is in progress on the phytochemical and pharmacological analysis of the plants. This study is important to preserve the knowledge of medicinal plants used by the people of the West Bank regions. Also, it is of significance to utilize new therapeutic natural plant products in various treatments of diseases. Moreover, clinical studies approved according to international guidelines should be considered in order to prove the safety and efficacy of treatment, especially for the most frequently reported medicinal plants.

\section{Conclusion}

Many plant species are still used by herbalists and traditional practitioner healers in Palestine for treating various types of cancer. This article provides the knowledge about anticancer medicinal plants of local and foreign origin, which are used by the people all over the Palestinian area in addition to their method of preparation. Many of the used plants have been approved scientifically to have some anticancer activity. A combined scientific effort between informants and the scientific community working in this field may help in the discovery of new anticancer agents. Moreover, scientists may explore the most convenient method of extraction, formulation and dose determination in order to achieve the best benefit from these plants.
Further scientific laboratory studies are required to explore and to investigate the safety and efficacy of these plants, their potential therapeutic effects as well as probable interactions of these medicinal products with conventional anticancer medicines.

\section{Competing interests}

The authors declare that they have no competing interests.

\section{Authors' contributions}

Nidal Jaradat conceived, accomplished and designed the study, Rowa Al-Ramahi, Abdel Naser Zaid, Ola Ayesh and Ahmad Mustafa Eid carried out the data obtained and drafted this paper. All researchers collected the data from local herbal practitioners and revised and approved the final manuscript. All authors read and approved the final manuscript.

\section{Acknowledgements}

This study was not funded by any institution. We would like to thank Dr. Cynthia Anderson for her help in language reviewing, all the herbalists and herbal practitioner healers in the West Bank/ Palestine and all participants in the study.

Received: 25 November 2015 Accepted: 2 March 2016

Published online: 08 March 2016

\section{References}

1. Mendelssohn H, Yom-Tov Y. Mammalia of Israel. Fauna Palaestina. Israel Academy of Sciences: Jerusalem; 1999.

2. Lev E. Ethno-diversity within current ethno-pharmacology as part of Israeli traditional medicine. J Ethnobiol Ethnomed. 2006;2:2-4.

3. Azaizeh H, Saad B, Khalil K, Said O. The state of the art of traditional Arab herbal medicine in the Eastern region of the Mediterranean: a review. Evid-Based Compl Alt Med. 2006;3:229-35.

4. Azaizeh H, Saad B, Cooper E, Said O. Traditional Arabic and Islamic medicine, a re-emerging health aid. Evid-Based Compl Alt Med. 2010;7:419-24.

5. Ben-Arye E, Samuels N. Homeopathy on the crossroads of traditional and integrative medicine in the Middle-East. J Med Person. 2015;13:65-71.

6. Saad B, Azaizeh H, Said O. Tradition and perspectives of Arab herbal medicine: a review. Evid Based Complement Alternat Med. 2005;2:475-9.

7. Ghorbani A. Clinical and experimental studies on polyherbal formulations for diabetes: current status and future prospective. J Integr Med. 2014;12:336-45.

8. Ehrenreich B, English D. Witches, Midwives, and Nurses: A History of Women Healers (Contemporary Classics). Cuny: Feminist Press; 2010.

9. Solecki RS. Shanidar IV, a Neanderthal flower burial in northern Iraq. Science. 1975;190:880-1.

10. Booker A, Johnston D, Heinrich M. Value chains of herbal medicines-Research needs and key challenges in the context of ethnopharmacology. J Ethnopharmacol. 2012;140:624-33.

11. Manandhar NP. A survey of medicinal plants of Jajarkot district. Nepal J Ethnopharmacol. 1995:48:1-6.

12. Sahoo N, Manchikanti P, Dey S. Herbal drugs: standards and regulation. Fitoterapia. 2010;81:462-71.

13. Madhuri S, Pandey G. Some dietary agricultural plants with anticancer properties. Plant Arch. 2008;8:13-6.

14. Sivalokanathan S, Ilayaraja M, Balasubramanian M. Efficacy of Terminalia arjuna (Roxb.) on N-nitrosodiethylamine induced hepatocellular carcinoma in rats. Indian J Exp Biol. 2005;43:264-7.

15. Pihlak R, Liivand R, Trelin O, Neissar H, Peterson I, Kivistik S, et al. Complementary medicine use among cancer patients receiving radiotherapy and chemotherapy: methods, sources of information and the need for counselling. Eur J Cancer Care. 2014;23:249-54.

16. Rosangkima G, Prasad S. Antitumour activity of some plants from Meghalaya and Mizoram against murine ascites Dalton's lymphoma. Indian J Exp Biol. 2004;42:981-8.

17. Ovadje P, Roma A, Steckle M, Nicoletti L, Arnason JT, Pandey S. Advances in the Research and Development of Natural Health Products as Main Stream Cancer Therapeutics. Evid-Based Compl Alt Med. 2015;2015:12. 
18. Bray F, Ren JS, Masuyer E, Ferlay J. Global estimates of cancer prevalence for 27 sites in the adult population in 2008. Int J Cancer. 2013;132:1133-45.

19. Jemal A, Bray F, Center MM, Ferlay J, Ward E, Forman D. Global cancer statistics. CA Cancer J Clin. 2011;61:69-90.

20. Siegel R, Naishadham D, Jemal A. Cancer statistics, 2012. CA Cancer J Clin. 2012;62:10-29.

21. Jacobson M, Earle CC, Price M, Newhouse JP. How Medicare's payment cuts for cancer chemotherapy drugs changed patterns of treatment. Health Aff. 2010;1391-9.

22. Kathiresan K, Boopathy NS, Kavitha S. Coastal vegetation-an underexplored source of anticancer drugs. Nat Prod Rad. 2006;5:115-9.

23. Koduru S, Grierson D, Afolayan A. Ethnobotanical information of medicinal plants used for treatment of cancer in the Eastern Cape Province. South Africa Curr Sci. 2007;92:906-8.

24. Wood AJ, Shapiro CL, Recht A. Side effects of adjuvant treatment of breast cancer. N Engl J Med. 2001;344:1997-2008.

25. Simoben C, Ibezim A, Ntie-Kang F, Nwodo J, Lifongo L. Exploring Cancer Therapeutics with Natural Products from African Medicinal Plants, Part l: Xanthones, Quinones, Steroids, Coumarins, Phenolics and other Classes of Compounds. Anticancer Agents Med Chem. 2015;15:1092-111.

26. Sharma S, Gupta R. Drug Development from Natural Resource: A Systematic Approach. Mini Rev Med Chem. 2015;15:52-7.

27. Yesilada E. Contribution of traditional medicine in the healthcare system of the Middle East. Chin Journal Integr Med. 2011;17:95-8.

28. Gazzaneo LRS, De Lucena RFP, de Albuquerque UP. Knowledge and use of medicinal plants by local specialists in an region of Atlantic Forest in the state of Pernambuco (Northeastern Brazil). J Ethnobiol Ethnomed. 2005;1:1-8.

29. Heinrich M, Ankli A, Frei B, Weimann C, Sticher O. Medicinal plants in Mexico: Healers' consensus and cultural importance. Soc Sci Med. 1998:47:1859-71.

30. Friedman J, Yaniv Z, Dafni A, Palewitch D. A preliminary classification of the healing potential of medicinal plants, based on a rational analysis of an ethnopharmacological field survey among Bedouins in the Negev Desert. Israel J Ethnopharmacol. 1986:16:275-87.

31. Kipkore W, Wanjohi B, Rono H, Kigen G. A study of the medicinal plants used by the Marakwet Community in Kenya. J Ethnobiol Ethnomed. 2014;10:24-8.

32. Orhan IE. Pharmacognosy: Science of natural products in drug discovery. Bioimpacts. 2014;4:109-10.

33. Li L, Zhou X, Li N, Sun M, Lv J, Xu Z. Herbal drugs against cardiovascular disease: traditional medicine and modern development. Drug Discov Today. 2015;20:1074-86

34. Lanzotti V. Drugs based on natural compounds: recent achievements and future perspectives. Phytochem Rev. 2014;13:725-6.

35. Ali-Shtayeh MS, Jamous RM, Jamous RM. Herbal preparation use by patients suffering from cancer in Palestine. Complement Ther Clin Pract. 2011;17:235-40

36. Ben-Arye E, Schiff E, Hassan E, Mutafoglu K, Lev-Ari S, Steiner M, et al. Integrative oncology in the Middle East: from traditional herbal knowledge to contemporary cancer care. Ann Onco. 2012;23:211-21.

37. Alzweiri M, Sarhan AA, Mansi K, Hudaib M, Aburjai T. Ethnopharmacological survey of medicinal herbs in Jordan, the Northern Badia region. J Ethnopharmacol. 2011;137:27-35.

38. Seid MA, Tsegay BA. Ethnobotanical survey of traditional medicinal plants in Tehuledere district, South Wollo. Ethiopia J Med Plants Res. 2011;5:6233-42.

39. Jaradat N. Ethnopharmacological survey of natural products in palestine. An-Najah Univ J Res. 2005;19.

40. Said O, Khalil K, Fulder S, Azaizeh H. Ethnopharmacological survey of medicinal herbs in Israel, the Golan Heights and the West Bank region. J Ethnopharmacol. 2002;83:251-65.

41. Ali-Shtayeh MS, Jamous RM. Herbal medicines in cancer care in the Palestinian Authority. Eur J Integr Med. 2011;3:125-31.

42. Hudaib M, Mohammad M, Bustanji Y, Tayyem R, Yousef M, Abuirjeie M, et al. Ethnopharmacological survey of medicinal plants in Jordan, Mujib Nature Reserve and surrounding area. J Ethnopharmacol. 2008;120:63-71.

\section{Submit your next manuscript to BioMed Central and we will help you at every step:}

- We accept pre-submission inquiries

- Our selector tool helps you to find the most relevant journal

- We provide round the clock customer support

- Convenient online submission

- Thorough peer review

- Inclusion in PubMed and all major indexing services

- Maximum visibility for your research

Submit your manuscript at www.biomedcentral.com/submit
C Biomed Central 